\title{
Job Quality and Gender Inequality: Key Changes in Québec over the Last Decade
}

\author{
LUC CLOUTIER \\ Institut de la statistique du Québec and Université de Montréal, Montréal, Québec, Canada
}

PAUL BERNARD

Université de Montréal, Montréal, Québec, Canada

DIANE-GABRIELLE TREMBLAY ${ }^{1}$

Télé-université de l’Université du Québec à Montréal, Montréal, Québec, Canada

\begin{abstract}
Using a new typology based on information available from the Labour Force Survey, the authors analyse how job quality evolved in Québec for both women and men over the last decade (1997-2007). Results show that family situation and educational attainment are two important factors in the determination of gender inequality in the labour market. The analysis emphasizes the very significant decline in gender differences with regard to job quality (from 23\% to 35\% according to groups), especially for persons without children and individuals who achieved higher education. The changes represent a definite progress in the status of women in general, although some indicators also reveal degradation with respect to job quality in some of the sub-groups.
\end{abstract}

\section{Introduction}

The significant increase in the presence of women in the labour market is one of the most important events to have occurred over the last three decades. Job feminization has grown to become a regular feature in most OECD countries (Cooke-Reynolds \& Zukewich, 2004; Fullerton, 1999; International Labour Organization [ILO], 2007; Johnston, 2005). Such massive integration, however, has led to very different forms of employment and working conditions which often tend to increase gender inequality. ${ }^{2}$ Even where differences between wage earning men and women have strongly decreased in terms of their respective numbers, female employees fare less well than their male counterparts. Women often hold less lucrative jobs, are more often confined to part-time work against their will or to short-term employment, and

\footnotetext{
Correspondence Address: Luc Cloutier, Institut de la statistique du Québec, Montréal, QC H3B 4J8, Canada. Tel: +1 514 876-4384 Email: luc_cloutier@sympatico.ca

Paul Bernard, Département de sociologie, Université de Montréal, Montréal, QC H3C 3J7, Canada. Tel:

+1 514 343-6111, Email: paul.bernard@umontreal.ca

Diane-Gabrielle Tremblay, Télé-université, Université du Québec à Montréal, Montréal, QC H2X 3P2,

Canada. Tel: +1 514 843-2015, Email: dgtrembl@teluq.uqam.ca
} 
are given fewer opportunities to deploy and establish their skills because they are given jobs and assignments that require little, if any, proficiency or aptitude (Cranford, Vosko, \& Zukewich, 2003; Hughes, Lowe, \& Schellenberg, 2003; Johansson, Katz, \& Nyman, 2005; Kim \& Kurz, 2001; Lemière \& Marc 2006). Persistent gender inequality wears more than one mask and may conceal true social injustice.

Although they have gained equal footing with men in their level of schooling (Statistics Canada, 2006a) and filled the education gap, women still cannot achieve their full potential and access complete socioeconomic independence in less prominent grades of professional occupations or employment status; women are more likely to depend on a spouse's or on someone else's immediate support, financially or otherwise. Gender disparity, however, is not limited to the labour market: there are acute gender issues as well in the division and sharing of family responsibilities. The uneven distribution of domestic and professional work between men and women (Tremblay, 2008) leads women, although they are part of the workforce, to assume responsibility for more family chores than men; on the other hand, men shoulder more responsibility for financial resources through work. Actually, both threads reinforce each other in maintaining women in an inferior situation in both spheres (Boje 1996; Maruani, 2000; Hirata \& Kergoat, 1998).

This paper analyses how work quality has evolved for women and for men in Québec over the last decade, using a new multidimensional typology we created, based on the information available in the Labour Force Survey. But first, it is useful to proceed to a quick review of the literature on the subject, in order to outline the relevant theoretical underpinnings, to describe the design and the methodology that lead to the typology we developed, and finally, the analytic process applied to the data.

\section{Review of the Literature}

One may use several theoretical perspectives to highlight the factors involved in the gender differences or inequalities in the labour market. We shall first examine these factors and then move on to the issue of job quality.

\section{Theories Explaining Disparities between Men and Women}

According to occupational segregation theory (Anker, 1997) unequal situations in the domestic sphere often lead women to similarly unfavourable circumstances in their professional life. As mentioned by Maruani (2000, p. 47), "the concept behind a gendered division of work proposes a critical approach to the distribution of the activities. First, it indicates that work is not distributed in a neutral fashion, and that men and women hold different positions in the world of professional and domestic work." In the domestic sphere, a sexual division of labour would subsist with reference to the relationships between genders, and such realities are likely to transfer into the professional sphere (Due Billing \& Alvesson, 1998; Tremblay, 2004). Other authors have shown the impact of the gendered division of labour, with women in a less favourable professional status in terms of earnings and working 
hours (Anker, 1997; Armstrong \& Armstrong, 2001; Boje 1996; Daune-Richard, 1998; Silvera, 1998).

But the gendered division of labour cannot explain everything. Gender discrepancies in the labour market finds another explanation in the theory of compensating differentials (Anker, 1997; Boisard, Cartron, Gollac, \& Valleyre, 2002; Godechot \& Gurgand, 2000; Joly, 2006): women would "wilfully” seek lower quality and professionally less demanding jobs, involving lower wages, part-time or temporary employment, requiring limited skills, but jobs that are compatible with their family situation; men, on the contrary, would seek better quality jobs (stable, high wages, full-time) and with more stringent requirements. In this perspective, men play the male provider role and women make a secondary income available to the household. Although this theory doesn't quite fit today's social reality, it remains somewhat relevant since many families with children still operate along this scheme of supplementary income, with men involved more substantially in the paid labour market.

New analyses, however, have shown a definite change in women's participation to household income in Canada (Marshall, 2006; Sussman \& Bonnel, 2006). The very noteworthy enhancement of women's qualifications in the last decades certainly comes into play in this respect and, following the human capital theory (cf. Schultz, 1961; Becker, 1975), it is deemed that women should progressively improve their professional standing as a result; indeed the human capital theory states that wage earnings are established according to the marginal productivity of labour, at least in the framework of the neoclassical theories of labour and capital (Tremblay, 2004). Gendered wage discrepancies are, according to this theory, due in part to differences in human capital between men and women. Owing to family responsibilities, women would acquire less human capital than men, and this would prevent them from accumulating one of the main components of human capital, work experience, the other significant factor being education: "The assumption of these models is that responsibility for family and household work induces women to interrupt their labour force participation and to work part time. Besides the direct effect this has on wages, it reduces the incentives for women to 'invest in human capital'” (Johansson, Katz, \& Nyman, 2005, p. 343).

This being said, a fair number of women possess strong human capital that is not necessarily recognised in the job market on an equal footing with that of men. Actually, the phenomenon of professional over-qualification unquestionably affects women more than men, at least in Québec (Cloutier 2007; Gagnon, 2008). How is it that women cannot capitalize on their full potential and adequately move to good jobs that are more in keeping with their skills? Theories that deal with discrimination offer a relevant explanation in this regard: women may face different types of discriminations in access to both jobs and equal wages. Joly (2006), Havet (2003), Johansson, Katz and Nyman (2005) and Anker (1997) indeed mention discrimination based on preferences, statistical discrimination, and professional segregation. Each of these theories, in their own way, attempt to explain that certain jobs, mostly held by women, are not recognized adequately when compared to jobs more often held by male workers. The lesser recognition of female work (lower wages in particular) is a form of discrimination that further generates barriers to the forward thrust of women on the job market. Career disruptions or disturbances, lesser or different work experience, productivity decline and family responsibilities would also contribute to 
women's uneven access to promotions and to better paid jobs (Avellar \& Smock, 2003; Budig \& England 2001; Hersh, 1991; Kalleberg \& Rosenfeld, 1990; Mandel \& Semyonov, 2005; Pernal, 2001; Raley, Mattingly, \& Bianchi, 2006;).

This quick overview indicates that gender differences in the labour market are a multi-dimensional issue and are of concern to human capital and its enhancement; they are rooted in family responsibilities and in discrimination as well. We therefore need to design a multi-dimensional approach to understanding how job quality differences have evolved between men and women in Québec over the last decade.

In order to cover the different aspects of the processes affecting women's (and men's) employment issues, we will define work quality with respect to the various component dimensions of the question: wages, working hours, skills and job stability. We will observe that men and women are in different positions despite the fact that the discrepancies have regressed over the years. More importantly, we will examine in detail how gender differences came to evolve as a function of educational attainment and family status; these two factors offer additional insights into the situation.

\section{Job Quality}

The concept of job quality is particularly useful in the study of gender inequalities. We will see how the concept may be used to highlight the trade-offs among available jobs. Given the constraints and opportunities involved in their participation in the job labour market, including educational attainment and family status, female and male workers are offered various types of jobs by firms who largely determine the working conditions of various groups; the ensuing jobs may be seen in terms of a package of working conditions that may-or may not—be acceptable to individuals, but which they do not always have a choice to accept, given their personal characteristics or level of education. This is the issue that we wish to bring to light with our job quality typology.

There is no exact or precise definition of job quality. The concept is very polysemic: the meaning varies according to the data used and the research perspective (CEE 2006; Drolet \& Morissette, 1998; Green 2006; Hughes et al., 2003; Khran, 1992; Meisenheimer, 1998; OECD, 2001; Rose, 2005). Generally, however, research has embraced at least three fundamental dimensions: remuneration, stability in the employment relationship, and working hours (Anker, Chernyshev, Egger, Mehran, \& Ritter, 2003; Handel, 2005; European Commission, 2001; European Foundation for the Improvement of Living and Working Conditions, 2002; Kalleberg, Reskin, \& Hudson, 2000; Lemière \& Marc, 2006; Lowe, 2007; McGovern, Smeaton, \& Hill, 2004; Rose, 2005) All of these dimensions are present in most studies focusing on job quality, and they thus provide the basis of the concept reviewed here.

In a recent study, Cloutier (2008) developed a conceptual framework for job quality in order to give shape to the concept. Based on key studies carried out on the subject in the last decade, we can identify nine dimensions of job quality: remuneration, work leaves, pension plans, group insurance, working hours, working schedules, stability, skills, and physical and psychological conditions. These indeed 
provide a rather comprehensive definition of "job quality." Other dimensions often pointed out in studies pertaining to job quality refer instead to characteristics of the labour market or of the work per se, for example minimum work standards, unionization, occupational injuries, work-family balance, professional autonomy, working climate, professional recognition, employee involvement in decisions, etc.

While it is impossible to pinpoint a single, consensual definition of job quality, it remains important to identify which dimensions should come into play because it is unrealistic to attempt studying them all at once. We also need to take into account the availability of data since we wish to determine how the phenomenon has evolved over time in Québec. ${ }^{3}$ We are, therefore, limited to the data provided in the regular surveys carried out by statistical agencies; we cannot focus on dimensions that add to the richness but for which sets of data may be lacking uniformity or regularity, or be altogether non-existent.

Studies dealing with gender differences in employment and working conditions often refer to the above mentioned fundamental conditions (remuneration, work duration, and employment stability), but they are explored one at a time. (Commission of the European Communities, 2008; European Foundation for the Improvement of Living and Working Conditions, 2008; Statistics Canada, 2006b). But the working realities for men and women are rather polymorphic and involve countless configurations. Moreover, it is necessary to combine the various dimensions in order to appraise the trade-offs that women and men make in selecting jobs: since they will not get all that they want in most cases, they will seek an adjustment between the various features of their jobs and the characteristics of their personal situation, in particular their education and their family responsibilities.

\section{Constructing a Typology of Job Quality-Methodology}

The construction of a typology must obey two fundamental requirements. Firstly, it must provide a sense of the quality of employment that will take into account all the key dimensions for which good data are available. As was seen above, at least three dimensions appear to be necessary and to offer good data: remuneration, stability and working hours. Secondly, several aspects of job quality combined into types, so that it becomes possible to highlight the trade-offs at play on the job market and that shape job quality. While it is relatively easy to identify the jobs that provide very high quality conditions from those that offer hardly any, the intermediate configurations need to be carefully identified in a multidimensional typology. The intermediate items reflect the multiple trade-offs that occur on the labour market between what is offered by employers, subject to their competitive environment, and what is wanted by workers, subject to their personal situation and professional aspirations, all of this resulting in the job quality situation. There will be jobs in which stability may be acquired at the cost of marginal remuneration and long working hours, and others where sizeable remuneration is obtained at the cost of endless hours, and so forth. Such configurations are presented below in order to systematically represent labour market inequalities and their distribution according to gender.

In Canada, the main source of data available to satisfy our requirements is Statistics Canada's Labour Force Survey (LFS). The LFS provides on a monthly 
basis, since $1997,{ }^{4}$ the most significant elements on employment and work conditions. Beyond the three basic dimensions of job quality, the LFS allows for the integration of another significant characteristic: skills. ${ }^{5}$ This is fortunate, since skill level and the ability to use one's skills are a major component of job quality, often referred to in the literature.

\section{A Four-Dimension Typology}

Figure 1 shows the cross-classification of the four leading dimensions (remuneration, skills, stability, and working hours), with the categories associated with each ${ }^{6}$. As one can see, this yields 120 configurations for job quality. The higher quality job would entail an hourly rate of $\$ 25.00$ and more, high skills, stability and normal fulltime working hours (30-40 hours per week). At the other end of the spectrum, the lowest quality job entails an hourly rate under \$10.00 per hour, requires limited skills but is held by an over-qualified worker; it offers unstable conditions and short working hours (involuntary part-time).

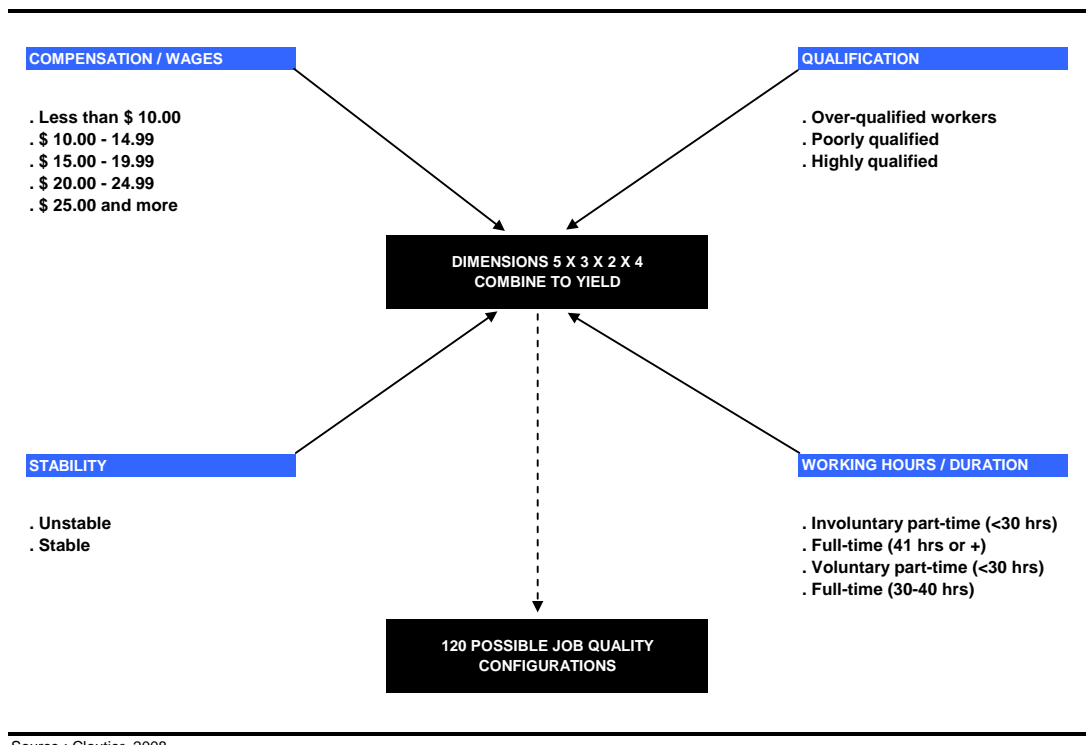

Figure 1. Schematic diagram of a job quality typology along four leading dimensions

Of course one cannot study job quality with a typology containing 120 configurations; an aggregation of the manifold configurations into a reasonable number of categories is necessary. Beyond job categories that provide the highest quality and very low quality, one must group these configurations into categories that convey different patterns of intermediate job quality.

We have developed such a classification scheme (Cloutier, Bernard, \& Tremblay, 2008; Cloutier 2008). Overall, twelve job categories or job groups were identified in 
order to reflect the main features of job quality, while leaving in each category a number of sample cases that will allow further analysis according to the various other characteristics of individual workers and of the labour market. Figure 2 provides a visual representation of the results, and the next paragraphs describe the twelve job categories.

\section{Group 1}

In many of the studies analysing the labour market and job quality (notably European research), involuntary part-time work is a category in itself because it shows a strong discrepancy between the workers' aspirations and the possibilities offered by the labour market or the employment at hand.

The fact that workers may not obtain more working hours may be a significant indicator of job insecurity and remuneration may especially be deemed unsatisfactory by those who hold such jobs.

Involuntary part-time work is a disincentive to the workers' integration because they cannot fully establish their skills even where they hold positions that require the skills they possess. In view of the qualitative aspect of this argument, we have established a category specific to involuntary part-time work in our typology.

On the quantitative side, the number of employees holding this type of job is relatively small (156,300 in 1997, about $6.6 \%$ of the entire workforce). In this group, not only are the jobs involuntary part-time, but most of them are stable, they require various levels of skills and $70 \%$ are poorly paid (less than $\$ 15.00 / \mathrm{h}$ ).

\section{Groups 2 to 8}

While involuntary part-time employment is unsatisfactory or inadequate for the workers, we may nevertheless consider that those who choose this work regime (whatever their rationale) find themselves in an acceptable if not favourable situation. Since the employee wishes to work fewer hours, the question relating to the remuneration (employment gains) may well be less of a concern.

Voluntary part-time work is thus a way to accommodate different activities, and to avail oneself of somewhat more flexibility. ${ }^{7}$ Regular employment between 30 and 40 hours per week is also likely to satisfy workers inasmuch as it provides them with acceptable revenues and allows them, to a certain extent, to articulate work with other activities. It is understood that normal jobs (30-40 hours) are less likely to conflict with other social times (such as family responsibilities, domestic work, leisure and rest, among others) than jobs entailing longer hours (41 hours or more).

In addition, we may consider that where this type of job is stable, it offers improved quality because employees benefit from such schedules over a longer time horizon. From the standpoint of job quality, it seems appropriate to aggregate voluntary part-time jobs (less than 30 hours/week) and normal employment (30-40 hours), since they share stability as a defining characteristic.

The vast majority of jobs are stable and offer normal working hours (full time, 30-40 hours) or voluntarily shortened working schedules (voluntary part-time). For example in 1997, two out of three workers $(1,554,800)$ share these characteristics. Given the large number of workers involved in this type of job, we were able to create seven groups displaying salient differences with respect to other dimensions, namely skills and remuneration. 
We first considered the jobs classified in one of the three possible skill levels (high skills, low skills, over-qualified), yet with low remuneration (less than $\$ 15.00$ per hour). Workers in this job category are distributed as follows: 10.3\% (or 244,800) in group 2 (high skills), 12.4\% (or 293,000) in group 3 (low skills) and 6.8\% (or 162,000 ) in group 4 (over-qualified workers). Next, we examine jobs that require higher skills and offer average to high remuneration $(\$ 15.00 / \mathrm{h}$ and more). The number of jobs requiring higher skills allowed for the creation of three groups of workers distributed as follows: 8.6\% (or 203,500) in group 5 (jobs with a remuneration between $\$ 15.00 / \mathrm{h}$ and $\$ 19.99 / \mathrm{h}$ ), $7.3 \%$ (or 172,200 ) in group 6 (between $\$ 20.00$ and $\$ 24.99$ per hour) and 9.8\% (or 231,100) in group 7 (\$25.00/h and more). Finally, a group featuring low skilled jobs or jobs held by over-qualified workers was created; this group includes jobs that nevertheless offer $\$ 15.00 / \mathrm{h}$ remuneration or more; it should be noted that in group 8 , two out of three jobs offer a remuneration ranging between $\$ 15.00$ and $\$ 19.99$ per hour. Overall, $10.5 \%$ of workers (or 248,200) held a group 8 job in 1997.

\section{Groups 9 and 10}

Compared to stable jobs, unstable employment usually offers limited professional perspectives (term contracts) and limited access to good remuneration and to other benefits. In 1997, 8.3\% of workers (or 195,600) held a job in this group. ${ }^{8}$ Where unstable jobs only are considered, the only other distinctive dimension or feature is wages: an unstable job with low remuneration is much more casual or risky than another unstable but better paid job. In view of these considerations and despite the fact that unstable employment includes a limited number of jobs, we chose to give weight to remuneration and distinguish between low-paid unstable jobs (less than $\$ 15.00 / \mathrm{h}$ ) and better paid unstable jobs ( $\$ 15.00 / \mathrm{h}$ and more): the former corresponds to group 9 and is populated by $4.2 \%$ of the workers (or 100,000), and the latter belongs to group 10 , which is made of $4.0 \%$ of the workers (or 95,600). It appears that low paid unstable jobs are mostly low skilled jobs (low skills and over-qualified workers), while better paid unstable jobs are mostly high skills jobs. Finally, most jobs in groups 9 and 10 offer regular work duration (30-40 hours).

\section{Groups 11 and 12}

Studies that investigate occupational health and work-life balance also underline the impact of work duration on workers. To be specific, long working hours may affect one's physical and mental health, for example where rest periods are inadequate (reduced sleep or sleep deprivation, lack of leisure times) and where it is difficult to sustain a healthy lifestyle (inadequate diet, lack of physical exercise, etc.). Moreover, being forced to perform long working hours may induce high levels of stress because workers cannot spare enough time for other activities, such as fulfilling their obligations or simply attending to their own needs. This is especially true of parents of young children, who must bear significant family duties. Time shortage induces sustained stress, which may in turn generate other problems, whether professional or personal. 


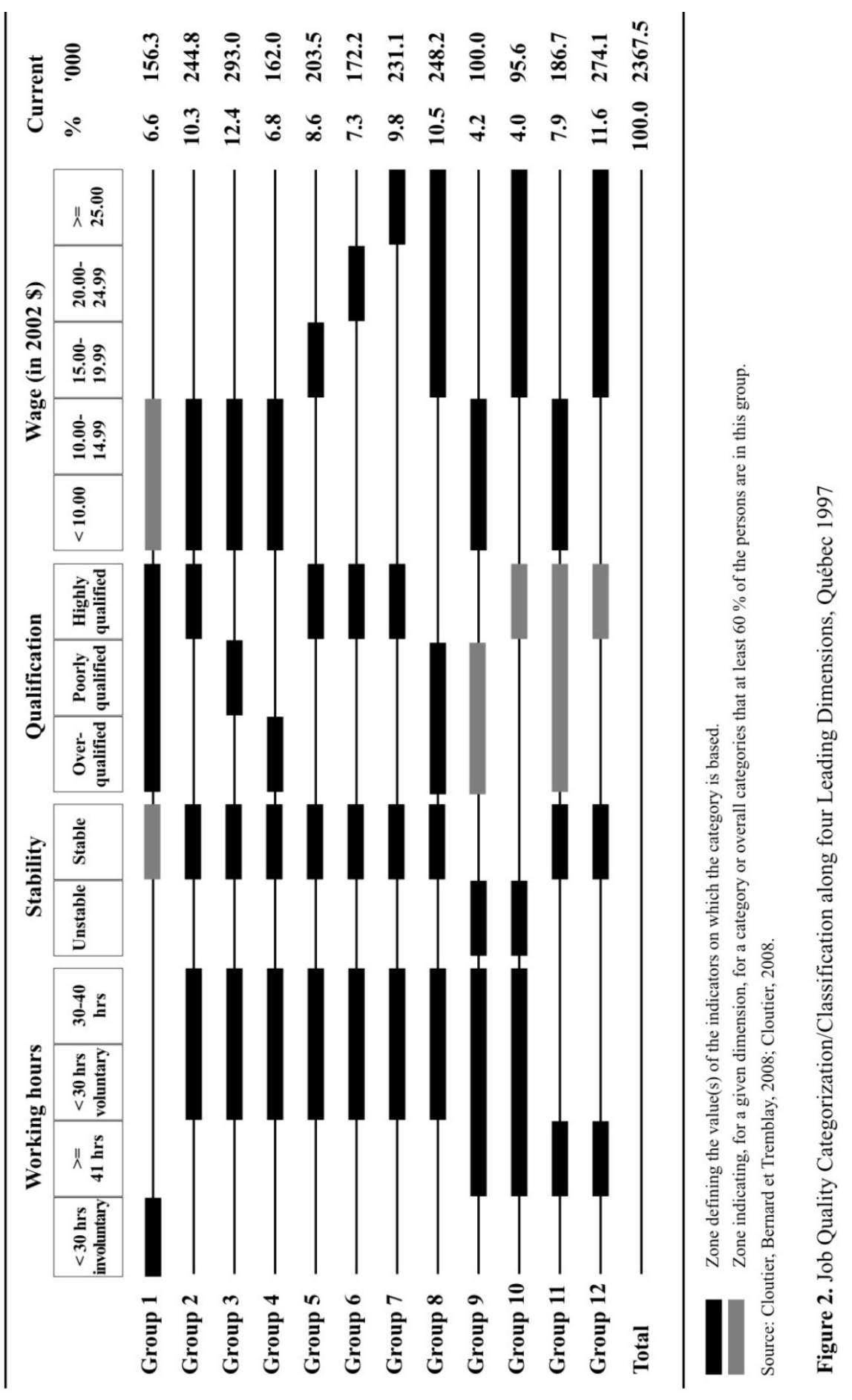


Long-hours jobs display one very important facet of job quality and therefore it is relevant to highlight this characteristic in the typology. In 1997, 21.0\% of workers (or 496,100) held a job that required long working hours (41 hours or more). Among all long-hours jobs, those that also feature volatility have already been included in groups 9 and 10. Yet, since the number of long-term and stable jobs is substantial, it remains possible to highlight the differences with the remuneration factor. We distributed the category into two groups; jobs with low remuneration (less than $\$ 15.00 / \mathrm{h}$ ) and better paid jobs (\$15.00/h and more). Long-term stable and low paid jobs (group 11) are held by $7.9 \%$ of workers (or 186,700), while better paid jobs (group 12) are available to $11.6 \%$ of workers (or 274,100). Group 11 jobs require various levels of skills while group 12 jobs are generally high skill jobs.

\section{Characterization of Job Quality Types}

The last step in the preparation of our job quality typology consists of associating identifiers to each of the 12 groups of job quality, in order to obtain a categorization of workers allowing the analysis of job quality for men and women. Where involuntary part-time workers are concerned (group 1), we will speak of constrained workers. Women and men who hold this type of job do face constraints since first and foremost they cannot work as much as they wish in their employment. Others whom we will call cheated workers hold jobs that feature low remuneration, and yet require high skills (group 2). While these persons are highly qualified and those skills are taken advantage of, they do not receive an adequate compensation, as do other workers. Low-end workers (group 3) are the workers who hold low skills and low paid jobs. These are also low skilled individuals. Their schooling status limits them to the lower rungs of job quality since they may hardly improve their situation. Downgraded workers (group 4) are highly qualified but seem to be unable to secure jobs that are in keeping with their professional profile. These persons are truly misplaced in the labour market, especially since they hold jobs with low remuneration that are however generally stable and regular.

Standard workers (group 5) enjoy quite acceptable employment conditions since they receive above average remuneration (between $\$ 15.00$ and $\$ 19.00$ per hour); they hold jobs that are in keeping with their skills and they (generally) work normal schedules in stable jobs. Group 6 is populated by privileged workers, who work under the same conditions and yet are paid between \$20.00 and \$ 24.99 per hour; on the labour market, these workers are among the most fortunate. Top-ranking workers in group 7 enjoy the same job quality as standard and privileged workers, but they are offered the highest wages (\$25.00 or more). Top-ranking workers sit at the top of the job quality classification. Established workers (group 8) hold low-skilled yet stable jobs that offer normal working schedules. This group of workers are better paid than bottom-rung or underprivileged workers, yet a large number are overqualified for the job. Since the remuneration, however, partly compensates for the skills mismatch, group 8 workers are somewhat trapped in their jobs, with comparative advantages perhaps designed to retain them but at a cost: the risk of seeing their skills and qualifications erode and vanish. 
Vulnerable workers (group 9) hold low quality jobs that are typically short-lived and poorly paid, while casual workers (group 10) enjoy better remuneration yet are confronted with job instability. Both group 9 and group 10 workers face job insecurity on the labour market. In group 11 heroic workers put in long hours in poorly paid jobs; they probably do so precisely because remuneration is slim. Finally, breathless workers (group 12) also put in long working hours but their jobs are better paid. It may be that they wish to secure a better income or are required to do overtime. Group 11 workers (heroic workers) hold jobs that require diverse skills, while group 12 workers (breathless workers) generally hold high skill jobs. Workers in groups 11 and 12 are usually rewarded with stable employment.

\section{Female/Male Job Quality Evolution in Québec}

Table 1 displays the dissimilarity coefficients ${ }^{9}$ between genders for 1997 and 2007. The coefficients indicate the global difference in the distribution of male and female workers within the 12 job quality groups defined above. Results are distributed according to family status and education levels of the persons since those are significant determinants of job quality for both women and men. In 1997, the coefficient was $26.6 \%$ for the entire working population. One decade later, it dropped to $18.4 \%$. This 8.2 percentage point dive is substantial: it corresponds to about one third of the initial difference. ${ }^{10}$

Table 1. Dissimilarity Coefficients between Genders Based on a 12-Group Typology of Job Quality: Results According to Family Status and Education Level, Québec, 1997 and 2007

\begin{tabular}{llccc}
\hline & \multicolumn{2}{l}{ Coefficient (in \%) } & \multicolumn{2}{c}{ Variation } \\
& & & \\
& 1997 & 2007 & in points & in \% \\
Aggregate & $\mathbf{2 6 . 6}$ & $\mathbf{1 8 . 4}$ & $\mathbf{- 8 . 2}$ & $\mathbf{- 3 0 . 8}$ \\
Persons without children & 21.1 & 13.7 & -7.4 & -35.1 \\
Persons with children & 33.5 & 25.8 & -7.6 & -22.8 \\
Persons with poor education/schooling & 32.1 & 24.7 & -7.4 & -23.0 \\
Persons with average education/schooling & 27.6 & 19.1 & -8.5 & -30.7 \\
Persons with high education/schooling & 24.1 & 17.3 & -6.8 & -28.2 \\
\hline
\end{tabular}

1. Poor education refers to high school education or less; average education means post-secondary, and higher education means completed university education or more.

Source: Statistics Canada, Labour Force Survey (LFS).

Calculations performed by the authors.

The data indicate that a definite narrowing of the gender gap occurred in job quality during the decade of 1997-2007 in Québec. Examining the situation of different groups of workers, one may note that the narrowing is especially significant for people without children (35.1\%) and that it is not so large for persons with children (22.8\%) or persons with little schooling (23.0\%) compared to approximately $30 \%$ for persons with higher education. It should be noted that the narrowing of 
differences actually occurs where differences were already less important in 1997. Persons without children offer a good illustration of this trend (data not shown): initial differences in the highly educated workers category were narrower than in the average schooling category and the dip is slightly lesser.

What happened? Table 2 offers an answer to this question by focusing on the evolution of the differences between genders for each type of worker over the period. One of the most significant findings in our analysis is that the most substantial reduction in the differences between genders occurred in the less advantageous categories of job quality. There is indeed a narrowing of the gap in the constrained workers group, in the cheated workers group (at the start of a career, probably), as well as in the downgraded workers group (younger and older workers, probably). These jobs are involuntary part-time jobs, they offer low income or require unskilled labour. Actually, the most significant narrowing of differences occurring in the constrained workers group (involuntary part-time jobs) concerns highly educated workers (more than 4 points of percentage); actually, in 2007, there is hardly any gender difference in this job category, while the weakest reduction in this respect is found in the category of workers with basic schooling only, for which gender differences remain the highest.

In the cheated workers category, persons with adequate skills which are drawn upon, but who receive low remuneration, the most significant reduction in malefemale job quality discrepancies occurs for persons without children and for persons with average schooling (almost four points). Gender discrepancies nevertheless remain sharp in the group of people who assume family responsibilities; discrepancies are higher among them than in any other category. Elsewhere, differences among low-end workers who assume family responsibilities tends to drop sizeably (reduction of 3 points). By and large gender differences remain, in 2007, twice as high in the category of persons with children than for workers without children.

Family responsibilities thus truly seem to affect gender differences with respect to job quality. This finding is given substance by the increase in the difference between men and women with children in the downgraded workers group, that is, persons who are over-qualified for the job and receive low remuneration (professionals at the start of a career, probably). The difference between men and women in this category is double that of persons without children.

Among the standard workers group, those who are paid between $\$ 15.00$ and \$19.99 per hour, who enjoy stable jobs in which their skills are recognized, and who generally work 30 to 40 hours per week, there is a drop in gender differences in all sociodemographic groups. However, in the (often unionized) top-ranking workers group where the best job quality is found, the most significant reduction occurs within the category of workers with higher education. Here, it is the human capital effect that comes into play. 


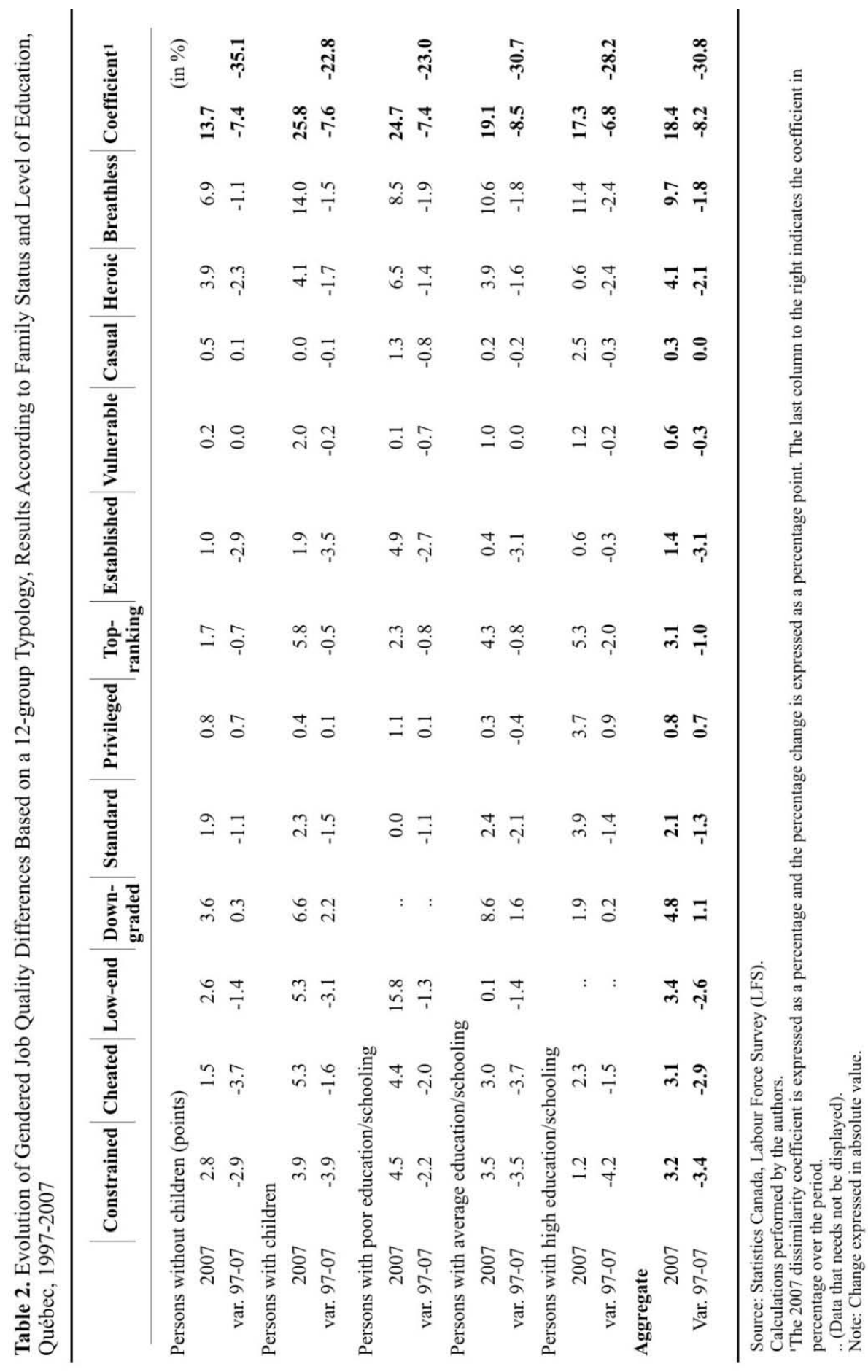


The substantial narrowing of gendered differences in the established workers group can be seen in all the groups except in the highly educated category, where discrepancies are negligible as we have seen at the outset. Whether they have children or not, whether they possess low or average schooling and training, workers who are well paid in jobs that require low skills display much narrower gender differences than before. It must be noted, however, that the gap is still significant in the category of persons with limited schooling (almost 5 points).

Finally, the overall drop in gender differences may also be analyzed by focusing on working time. Table 2 shows that there were significant reductions in the number of heroic workers and breathless workers. In the former group, which involves longterm but poorly paid jobs, there is a narrowing of the gap for all socioeconomic groups, but especially in two categories: persons without children and persons who completed higher education. The latter category is in fact the one which displays the most significant narrowing in the breathless workers group, that is, those who work long hours and receive very good pay. When both the heroic and the breathless groups of workers are examined-they are often found in the private sector or in management positions-we can see a narrowing of 5 percentage points in malefemale differences among those with higher education. No other swing of that magnitude can be observed elsewhere in the data. Nevertheless, working hours appear to play, just as well as remuneration and over-qualification, a major role in the reduction of gender differences in job quality.

Since a narrowing of gender differences in job quality does not necessarily translate into an overall improvement of job quality, we need to examine the situation of men and women in 2007 beyond the changes observed. For example, a smaller gap in the low-end category of workers could simply be driven by an increase of male workers in this group or a smaller gap in the breathless workers group could simply mean that more women have entered this group of workers. Table 3 displays the data required to proceed to such analysis. In a general way, it appears that changes in job quality occurred mainly among female workers, where indeed more important shifts occur, in the order of 2 points of percentage or higher.

Female constrained workers, for example, substantially decreased in number over the years. Drops of more than 4 points are noted in the categories of women with and without children, and of women who have completed average schooling. While the number of female constrained workers tends to decline overall, their number remains quite high among women with lower schooling; in 2007, female constrained workers with low schooling are twice as numerous as women with high education. Women's problems with finding more work or working more seems to relate to their human capital because there are no significant differences between women with children and women without children. Elsewhere, in the cheated workers group (highly qualified women in poorly paid job), persons without children lost some of their importance, while the number of women with children remained just about the same.

Since the latter type of job is of low quality and the proportion of women remains the same over the decade, it may well be that women with children still have problems balancing family and professional responsibilities if they hold high quality jobs. This finding, however, is not limited to this type of employment, since downgraded workers (women who are over-qualified and poorly paid) significantly 
increase their numbers over the period (by almost 4 percentage points). Such a situation is nowhere observed among women without children or among men with and without children. It appears, then, that women with children are subject to more social inequality than any other category of workers in accessing quality jobs.

However, other changes in the data on job quality show a significant improvement for women with children. Table 3 shows both a decrease in the number of female workers in the low-end group (down almost 5 percentage points) and a significant increase of their numbers in the top-ranking group (more than 3 points). These changes are the most important to have occurred for both men and women. In our view, this means that a number of female workers with parental obligations succeed in escaping or in avoiding very low quality jobs and actually access jobs that offer better, more suitable conditions. The data thus bring to light significant signs of change in the evolution of job quality for women.

Time devoted to family responsibilities, therefore, is still asymmetrically distributed between females and males, and gender discrepancies frequently translate into more working hours for men; more men hold jobs that require longer working hours (41 hours or more) in the labour market.

Data in Table 3 indicate changes in this respect. Over the period, there is a significant drop in the number of heroic workers (workers who work long hours for low wages) among men with children. No change occurs, however, for breathless workers, who work long hours in well paid jobs.

For men without children, the situation is similar to that of men with family responsibilities; however, the drop that occurs with heroic workers is more important than for men without family responsibilities. Up to this day, working time remains an issue for work-family balance. Although a number of workers work fewer hours, the changes observed in the data do not indicate any significant reduction of gendered inequalities with respect to work-family balance.

Workers who care for children and who hold top-ranking jobs have seen their numbers increase significantly between 1997 and 2007 (almost 3 percentage points), thus limiting the narrowing of the gap between men and women in that category. If gendered inequalities remain for this group of jobs, it must be said that the increase in the number of top-ranking workers who have children is the highest among all groups of male workers. If, moreover, the established workers group and the heroic workers group have definitively lost some ground among those who have children (down 2.5 and 2.9 percentage points respectively), it seems that the conditions to reconcile family and professional obligations are better today than they were ten years ago for men. However, the fact that this group improved its job quality situation more than any other explains in part why there was not a similar narrowing of the gender gap for workers with children compared to persons without children (down by $22.8 \%$ and $35.1 \%$ respectively). 


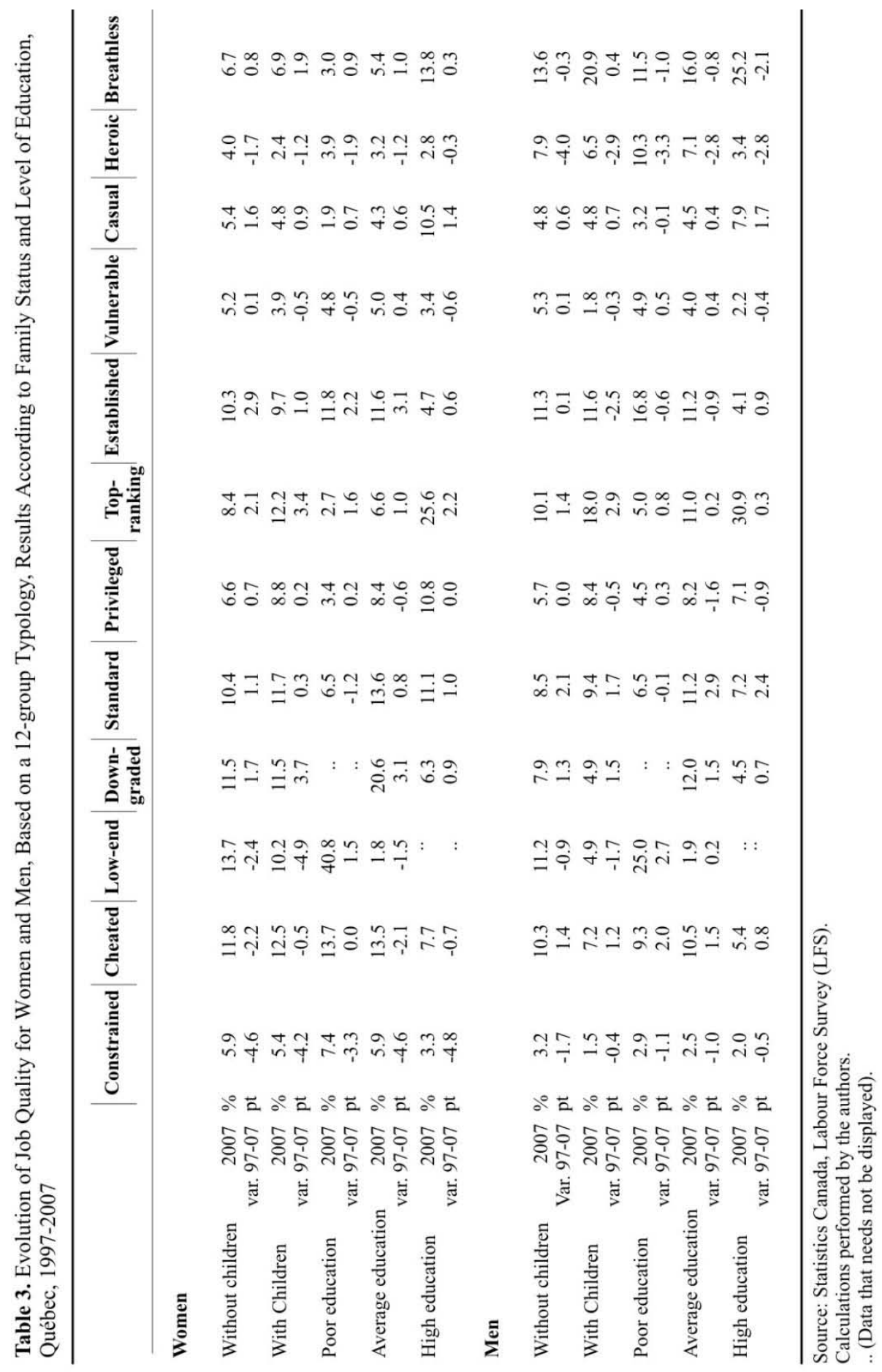


It comes as no surprise, then, that job quality did not improve for the category of persons with low schooling. Although the number of women with little schooling in the constrained workers group has dropped, other women with poor schooling have not really improved their situation over the period, except for the fact that there are fewer women in the heroic group of workers. For men, a significant decrease can be observed in the poorly schooled heroic workers (a drop of more than 3 percentage points), but this combines with a significant increase of men in the cheated workers group and in the low-end workers group. The situation of poorly schooled men and women thus improves in some respects, but it worsens elsewhere; this explains partly why the gender gap in job quality has not narrowed sizeably.

For persons with average schooling and training, multiple changes can be identified in women's job quality. The number of females who are constrained workers, cheated workers, and low-end workers has decreased, and this helps narrow the job quality gap with men. Men also contribute to the process, since their numbers drop significantly in the heroic workers group and rise sizeably in the standard workers group. Even more salient is the fact that the number of over-qualified women with average schooling increases dramatically over the period: more than 3 percentage points among downgraded workers and established workers. This situation is singular because no similar movement is observed among poorly schooled or highly educated workers. This increase in women's occupational overqualification illustrates the persistence of gendered inequalities in the labour market, in spite of the narrowing of the gap in other job categories. Female workers in Québec appear to experience serious discrimination even when they have undeniably improved their level of education, especially in comparison with men; women's additional education achievements do not seem to be as profitable to them as one would expect from human capital theory.

Finally, issues of remuneration and working hours are at the heart of changes in job quality for both women and men who enjoy higher education. Table 3 shows that female workers significantly increase their numbers in the top-ranking group of workers, while there is a sharp drop for women in the constrained workers group (almost 5 percentage points). For men, data shows a significant drop in the heroic workers group as well as in the breathless workers group; the combined decrease in these groups of workers is almost 5 percentage points. It may be said that access to well-paid jobs by highly educated women, combined to a significant drop in involuntary part-time jobs as well as the decline of highly educated men in jobs that require long working hours, has led to a major narrowing of the overall gender gap for this category of persons.

\section{Conclusion}

Our analysis of changes in the gap of male/female job quality in Québec over the last decade reveals both the shrinking of some differences and the persistence of a significant set of discrepancies. The latter are strongly related to family status and, therefore, to important gender inequalities with respect to family responsibilities in interaction with women's level of education. In general, the situation of women without children and that of highly educated women improves more consistently. 
Nevertheless, women who assume family responsibilities have registered significant gains. Issues relating to earnings, to professional skills, and to working hours remain at the heart of job quality discrepancies between genders. In some instances, women are able to leave low quality jobs, where limited working hours, low wages, and lowskills jobs are involved; and they make headway towards good-paying jobs. Men tend, rather, to modify their behaviour with respect to working time, regardless of family responsibilities and high or low education. It is worth noting that this type of change is less present when children are involved and more significant among those with higher education. Finally, professional over-qualification is more prevalent among female workers, especially those with children and with average schooling.

Despite the definite reduction of gender differences over the past ten years, all these findings draw up a portrait in diverse shades of grey for job quality changes in the Québec labour market. In light of the results presented, there should be no doubt that issues such as the gendered division of labour, human capital, and discrimination still play a key role in understanding these inequalities. More detailed analyses are required in order to better understand how professional and family dimensions interact to shape and alter the gender gap in job quality.

The reduction of gender inequalities in the Québec labour market over the last decade is sizable if not dramatic. A reduction by one third in the differences between women and men in Québec over such a short period is witness to this fact. The last decade has seen relatively strong economic growth, and this has no doubt contributed to a better integration of women in the labour market. But economic factors do not explain everything. Over the last decade, Québec has promoted progressive legislation and governmental measures aimed at enhancing gender equality (or equity) with respect to work and life outside the workplace. Among such actions, it is worth noting, are the Pay Equity Act (Loi sur l'équité salariale, 1997), the Employment Equity Act (reviewed in 2001) and several other measures involving family policies, including affordable childcare services (reduced contribution program implemented gradually, starting in 1997). ${ }^{11}$ The measures appear to have been instrumental in reducing gender inequalities in the labour market, especially with respect to job quality (Cloutier, 2007).

Given these circumstances, can we expect this trend will continue to continue in Québec? Will it lead to a convergence in the employment situation of women and men? This remains to be seen, especially in light of the recent economic downturn and the financial crisis. More often than not, women bear the brunt of economic downturns such as recessions (ILO, 2009; Trade Union Congress, 2009; Confédération syndicale international, 2009). Some believe, however, that the ongoing crisis is "sexist" in nature because it affects the economic sectors where jobs are mainly held by men, with the exception of the financial sector, so terribly struck, but including those sectors now supported by governments (for example the car manufacturing sector). For all intents and purposes, job quality issues will be at the heart of the debates on economic renewal. Should job quality tend to degrade, it may be expected that gender inequality will also increase. Workers, and especially women, who are less skilled or burdened with family responsibilities are likely to pay a higher price. A similar analysis to ours should thus be undertaken as we come out of the current crisis. 


\section{Notes}

1 Luc Cloutier is Statistical Analyst (Institut de la statistique du Québec) and doctoral candidate at the Université de Montréal. Paul Bernard is a Université de Montréal Professor and Diane-Gabrielle Tremblay is a TÉLUQ-UQAM Professor (Télé-université de l’Université du Québec à Montréal). The authors wish to extend their appreciation for the seminal comments provided by their three anonymous reviewers.

2 We use the expression "gender" to typify the social differences and disparities conveyed in the relationships between men and women both at work and outside the workplace. It is more relevant to use the "gender" concept than that of "sex" since the latter refers to the biological differences between women and men.

3 In addition, it is our intention to compare the situation in Québec with that of other Canadian regions in order to develop a better understanding of trends as they become salient.

4 Actually, remuneration and employment stability (permanent and temporary) were first included in the 1997 survey.

5 The "skills" dimension is used to classify the job into high or low skills; the former includes technical or professional occupations and management positions, and the latter includes intermediate or plain simple jobs. The classification reveals whether the worker is qualified or over-qualified for the job. A worker is over-qualified for a job when the minimum requirements of the job are lower than the candidate's level of education.

${ }^{6}$ The division into subset categories is explained in full detail in Cloutier (2008).

7 This may be the case of mothers returning to the labour market following maternity leave. Their choice of the part-time regime, however, does not necessarily entail that a quality job is available. Research by Gatrell (2007) has indeed shown that highly qualified mothers returning to part-time employment (as a percentage of full-time placement) has translated into curtailed career development opportunities and in some instances into accepting work designed for less qualified personnel.

8 Since all involuntary part-time jobs are included in Group 1, this figure excludes unstable involuntary part-time jobs.

${ }^{9}$ The dissimilarity coefficient indicates the proportion of individuals in one of the distributions being compared that would need to be moved to other groups in order to match its distribution with that of the other group. A zero (0) coefficient indicates that two groups (for example, women and men) display an identical distribution, while a $100 \%$ coefficient indicates the absence of one group in all the categories where the other group is present. The higher the coefficient, the steeper the differences between the groups being compared.

${ }^{10}$ For comparison purposes, the coefficient in Canada shifted from $26.8 \%$ to $20.4 \%$ for a $23.9 \%$ drop (or 6.4 percentage points). In Ontario, the drop is in the same range $(-22.5 \%$ or 5.9 percentage points) and in 2007 the coefficient is $20.2 \%$. Alberta's situation is atypical with a drop of $15.1 \%$ only in the coefficient, only half of that in Québec. That part of the western region displays a coefficient that remains very high at $26.9 \%$ in 2007 . Québec therefore presents a reduction in the differences between genders that is larger than in other Canadian region.

11 Lately, other measures were implemented in Québec; for example, enhanced parental leave providing mothers (as well as fathers) with a better replacement income over a longer period. The impact of this measure on women's job quality is still unclear, however, because it may well translate into a less profitable re-entry into the labour force (for more on this issue, Gatrell, 2007).

\section{References}

Anker, R. (1997). Theories of occupational segregation by sex: An overview. International Labour Review, 136(3), 315-339.

Anker, R., Chernyshev, I., Egger, P., Mehran, F., \& Ritter, J. A. (2003). Measuring decent work with statistical indicators. International Labour Review. 142(2), 147-177.

Armstrong, P., \& Armstrong, H. (2001). The double ghetto: Canadian women and their segregated work. Cambridge: Oxford University Press. 
Avellar, S., \& Smock, P. J., (2003). Has the price of motherhood declined over time? A cross-cohort comparison of the motherhood wage penalty. Journal of Marriage and the Family, 65(3), 597-607.

Becker, G. S. (1975). Human capital: A theoretical and empirical analysis, with special reference to education ( $2^{\text {nd }}$ ed.). New York, NY: Columbia University Press.

Boisard, P., Cartron, D., Gollac, M., \& Valeyre, A. (2002). Temps et travail: l'intensité du travail. Dublin: Fondation européenne pour l'amélioration des conditions de vie et de travail.

Boje, T. P. (1996). Gender, work time and flexible employment. Time and Society, 5(3), 341-361.

Budig, M. \& J., England, P. (2001). The wage penalty after motherhood. American Sociological Review, 66(2), 204-225.

Centre d'études de l'emploi. (2006). La qualité de l'emploi. Paris Éditions La Découverte

Cloutier, L. (2008). La qualité de l'emploi au Québec, développements conceptuels et création d'une typologie. État actuel de la réflexion. Québec: Institut de la statistique du Québec.

Cloutier, L., Bernard, P., \& Tremblay, D.-G. (2008). La qualité de l'emploi des femmes et des hommes au Québec: une étude de son évolution à l'aide d'une nouvelle typologie. , In D.-G. Tremblay (Ed.), Flexibilité, sécurité d'emploi et flexicurité: les enjeux et défis (pp. 107-132), Montreal: Presses de l’Université du Québec.

Cloutier, L. (2007). Effets de certaines politiques sociales sur la qualité de l'emploi des femmes au Québec. Flash-Info Travail et rémunération, 8(3), 1-5.

Commission of the European Communities. (2008). Report from the Commission to the Council, the European Parliament, the European Economic and Social Committee and the Committee of the Regions, Equality between women and men-2008. Brussels: Commission of the European Communities.

Confédération syndicale international. (2009). (In)égalité entre hommes et femmes sur le marché du travail: synthèse des tendances et evolutions mondiales. Brussels: CSI.

Cooke-Reynolds, M., \& Zukewich, N. (2004). The feminization of work. Canadian Social Trends, 2(72), 24-29.

Cranford, C. J., Vosko, L.F., \& Zukewich, N. (2003). The gender of precarious employment in Canada, Relations industrielles/Industrial Relations, 58 (3), 454-480.

Daune-Richard, A.-M. (1998). Qualifications et représentations sociales In M. Maruani (Ed.), Les nouvelles frontières de l'inégalité, hommes et femmes sur le marché du travail (pp. 47-58). Paris: Éditions La Découverte/Mage

Drolet, M., \& Morissette, R. (1998). Recent Canadian evidence on job quality by firm size. (Statistics Canada, No. 11F0019MPE No. 128) Ottawa: Statistics Canada.

Due Billing, Y., \& , M. (1994). Gender, managers and organization. Berlin: De Gruyter, 260 p.

European Commission, (2001). Employment in Europe 2001. Recent trends and prospects. Luxembourg: European Commission.

European Foundation for the Improvement of Living and Working Conditions. (2008). Annual review of working conditions in the EU 2007-2008. Luxembourg: Office for Official Publications of the European Communities.

European Foundation for the Improvement of Living and Working Conditions. (2002). Quality of work and employment in Europe: Issues and challenges. Luxembourg: Office for Official Publications of the European Communities.

Fullerton, Jr., H. (1999). Labor force participation: 75 years of change, 1950-98 and 1998-2005, Monthly Labor Review, 122(12), 3-12.

Gagnon, S. (2008). La surqualification: Qui la vit? Où s'observe-t-elle? Flash-Info Travail et rémunération, 9(3), 1-5.

Gatrell, C. (2007). A fractional commitment? Part-time work and the maternal body. The International Journal of Human Resource Management, 18(3), 462-475.

Godechot, O., \& Gurgand, M. (2000). Quand les salariés jugent leur salaire. Économie et statistique , 1(331), 3-24.

Green, F. (2006). Demanding work: The paradox of job quality in the affluent economy. Princeton: Princeton University Press.

Handel, M. J. (2005). Trends in perceived job quality, 1989 to 1998. Work and Occupations, 32(1), 6694.

Havet, N. (2003). Écarts salariaux et disparités professionnelles entre sexes: développements théoriques et validité empirique. (Document de recherche, no. 2003-11). Orléans, France : l'Université d’Orléans, Laboratoire d'Économie d’Orléans. 
Hersch, J. (1991). The role of human capital, working conditions, and housework. Industrial and Labor Relations Review, 44(4), 746-759.

Hirata, H., \& Kergoat, D. (1998). La division sexuelle revisitée In Maruani, M. (Ed.) Les nouvelles frontières de l'inégalité, hommes et femmes sur le marché du travail (93-104). Paris: Éditions La Découverte/Mage.

Hughes, K., Lowe, G., \& S., Schellenberg, G. (2003). Men's and women's quality of work in the new Canadian economy. Ottawa: Canadian Policy Research Network .

International Labour Organization. (2009). Global employment trends for women: March 2009. Geneva: International Labour Office.

International Labour Organization. (2007). Global employment trends for women. Brief: March 2007. Geneva: International Labour Office.

Johansson, M., Katz, K., \& Nyman, H. (2005). Wage differentials and gender discrimination, Acta Sociologica, 48(4), 341-364.

Johnston, G. (2005). Women's participation in the labour force. (Working Paper 05/06). Wellington: New Zealand Treasury.

Joly, C. (2006). L’écart de rémunération entre femmes et hommes: facteurs explicatifs et perspectives de solutions. Retrieved from http://www.egalite.cfwb.be/upload/album/AP_138.pdf.

Kalleberg, A. L., \& Rosenfeld, R. A. (1990). Work in the family and in the labor market: A cross-national, reciprocal analysis. Journal of Marriage and the Family, 52(2), 331-346.

Kalleberg, A. L., Reskin, B. F., \& Hudson, K. (2000). Bad jobs in America: Standard and nonstandard employment relations and job quality in the United States. American Sociological Review, 65(2), 256278.

Kim, A., \& Kurz, K. (2001). Precarious employment, education and gender: A comparison of Germany and the United Kingdom (Working Papers, $\mathrm{n}^{\circ}$ 39), Mannheim: Mannheimer Zentrum für Europäische Sozialforschung.

Krahn, H. (1992). Quality of work in the service sector. (General social survey analysis series, no. 6). Ottawa, ON: Statistics Canada.

Lemière, S., \& Marc, C. (2006). Qualité des emplois et genre: les effets croisés des statuts et des horaires de travail. Paris, France : Université Paris 1, Centre d’Économie de la Sorbonne.

Lowe, G. (2007). $21^{\text {st }}$ century job quality: Achieving what Canadians want. Ottawa: Canadian Policy Research Network.

Mandel, H., \& Semyonov, M. (2005). Family policies, wage structures, and gender gaps: Sources of earnings inequality in 20 countries, American Sociological Review, 70(6), 949-967.

Marshall, K. (2006). Converging gender roles. Perspectives on Labour and Income, 7(7), 5-17.

Maruani, M. (2000). Travail et emploi des femmes . Paris: Éditions La Découverte.

McGovern, P., Smeaton, D., \& Hill, S. (2004). Bad jobs in Britain: nonstandard employment and job Quality. Work and Occupations, 31(2), 225-249

Meisenheimer, J. R., II. (1998). The services industry in the 'good' versus 'bad' jobs debate. Monthly Labor Review, 121(2), 22-47.

Organisation for Economic Co-operation and Development (OECD). (2001). Chapter 3: Characteristics and quality of service jobs. In OECD Employment Outlook 2001 (pp 89-128). Paris: OECD Publishing.

Perna, L. W. (2001). The relationship between family responsibilities and employment status among college and university faculty. The Journal of Higher Education, 72(5), 584-611.

Raley, S. B., Mattingly, M. J., \& Bianchi, S. M. (2006). How dual are dual-income couples? Documenting change from 1970 to 2001. Journal of Marriage and Family, 68(2), 11-28.

Rose, M. (2005). Job satisfaction in Britain: Coping with complexity. British Journal of Industrial Relations, 43(3), 455-467.

Schultz, T. W. (1961). Investment in human capital (American Economic Association Presidential Address), The American Economic Review 1(2), 1-17.

Silvera, R. (1998). Les salaires: toutes choses inégales par ailleurs? In M. Maruani (Ed.), Les nouvelles frontières de l'inégalité, hommes et femmes sur le marché du travail (pp. 127-138).Paris: Éditions La Découverte/Mage.

Statistics Canada. (2006a). Chapter 4: Education. Women in Canada, A gender-based Statistical Report Catalogue No. 89-503-XPE (pp. 89-97). Ottawa, ON.

Statistics Canada, (2006b). Women in Canada: A gender-based statistical report Catalogue No. 89-503XPE. Ottawa, ON.

Sussman, D., \& Bonnell, S. (2006). Wives as primary breadwinners. Perspectives on Labour and Income, $7(8), 10-17$. 
212 Luc Cloutier, Paul Bernard, and Diane-Gabrielle Tremblay

Trade Union Congress. (2009). Women and recession: How will this recession affect women at work? Retrieved from http://www.tuc.org.uk/extras/womenandrecession.pdf.

Tremblay, D.-G. (2004). Économie du travail. Les réalités et les approches théoriques. Montréal: Éditions Saint-Martin.

Tremblay, D.-G. (2008). Conciliation emploi-famille et temps sociaux. Québec: Presses de l'université du Québec. 